\title{
IUCN RED LIST EVALUATION OF THE ORCHIDACEAE ENDEMIC TO APULIA (ITALY) AND CONSIDERATIONS ON THE APPLICATION OF THE IUCN PROTOCOL TO RARE SPECIES
}

\author{
Robert P. Wagensommer ${ }^{1}$, Pietro Medagli ${ }^{2}$, Alessio Turco ${ }^{2}$, Enrico V. Perrino \\ ${ }^{1}$ University of Bari «Aldo Moro», Italy \\ e-mail: robert.wagensommer@uniba.it \\ ${ }^{2}$ University of Salento, Italy \\ e-mail:pietro.medagli@unisalento.it,alessio.turco@unisalento.it \\ ${ }^{3}$ CIHEAM - Mediterranean Agronomic Institute, Italy \\ e-mail:perrino@iamb.it
}

Received: 18.05.2020. Revised: 20.06.2020. Accepted: 23.06.2020.

\begin{abstract}
The conservation status of the ten taxonomically currently recognised orchid species and subspecies (eight in the genus Ophrys, and one each in the genera Epipactis and Serapias) endemic to Apulia (southeast Italy) is presented. Each taxon has been assessed against the internationally accepted IUCN criteria and categories. Of the ten taxa, eight ones are classified as threatened (Endangered or Vulnerable), one as Near Threatened and one as Least Concern. Given that nine of the ten analysed taxa were recently assessed, a comparison with the previous assessments is presented: 67\% of the assessed taxa changed their IUCN category. Four taxa (Ophrys murgiana, O. oxyrrhynchos subsp. ingrassiae, $O$. peucetiae, $O$. tardans) are now assigned to a higher threat category, while two taxa (Ophrys gravinensis and $O$. oestrifera subsp. montis-gargani) are now assigned to a lower threat category. These category changes in such a very short time are due to the better knowledge on the number of mature individuals and on the threats affecting the species, and to the discovery of new occurring sites. The most important category change affects Ophrys tardans. The new assessment leads to the category Endangered, whereas in the previous assessment this species was indicated as Least Concern, i.e. as not threatened. Another species with a noteworthy category increase is Ophrys peucetiae, previously indicated as Least Concern and now assigned to the category Vulnerable. The authors discuss these results, highlighting that especially when assessing rare species with a small distribution range against the IUCN protocol, it should be taken into account that the assessment could be influenced (also noteworthy) by the effective knowledge on the distribution, on the population size and on the threats affecting the populations. As a consequence, field work is warmly suggested before assessing the threat category of rare taxa, given that an increased effort in field research often leads to the discovery of new sites and to a better estimation of the number of individuals and of the threats.
\end{abstract}

Key words: category change, conservation, distribution, endemism, extinction risk, orchids, Puglia, threats

\section{Introduction}

According to the recent checklist of the flora native to Italy (Bartolucci et al., 2018), in Italy the family Orchidaceae is represented by 234 taxa (species and subspecies), 86 of which are endemic to Italy, plus two doubtfully occurring taxa. Afterwards, five new species endemic to Italy were described in the genus Epipactis (Hertel \& Presser, 2019). The Italian administrative region with the highest orchids biodiversity is Apulia (101 occurring taxa), followed by Tuscany (100 occurring taxa) and Basilicata (97 occurring taxa).

From a floristic point of view, Apulia is well known not only for its richness in orchid species, but also for the abundance of orchid populations and of individuals in the populations (Gölz \& Reinhard, 1982; Lorenz \& Gembardt, 1987; Romolini \& Souche, 2012; AA.VV., 2016). Many botanists and amateurs from various European countries (especially from central Europe) come therefore to Apulia in spring. So the Orchidaceae family has also some eco- nomic importance for this Italian region. At the present state of knowledge, 101 currently occurring taxa (species and subspecies), one no longer recorded species (Ophrys insectifera L.) and one doubtfully occurring species (Ophrys bilunulata Risso) are reported from Apulia (De Leo, 2016; Bartolucci et al., 2018; Hertel \& Presser, 2019; Mascia \& Labadessa, 2019). The following ten taxa, eight in the genus Ophrys, and one in each of the genera Epipactis and Serapias, are endemic to Apulia: Epipactis garganica S.Hertel, Ophrys gravinensis D'Alonzo, O. mattinatae Medagli, A.Rossini, Quitadamo, D'Emerico \& Turco, $O$. murgiana Cillo, Medagli \& Margh., O. oestrifera M.Bieb. subsp. montis-gargani Van de Vijver \& W.Looken, O. oxyrrhynchos Tod. subsp. ingrassiae Dura, Turco, Gennaio \& Medagli, O. peucetiae Lozito, D'Emerico, Medagli \& Turco, O. pseudomelena Turco, Medagli \& D'Emerico, O. tardans O.Danesch \& E.Danesch, and Serapias orientalis (Greuter) H.Baumann \& Künkele subsp. apulica H.Baumann \& Künkele. In fact, Ophrys nicolae Q.G.Manni 
(Manni, 2016) is clearly a hybrid and probably has no taxonomic validity, and, despite to Peruzzi et al. (2014) and Wagensommer et al. (2014c), Ophrys bertolonii Moretti subsp. bertoloniiformis (O.Danesch \& E.Danesch) H.Sund is no more considered endemic to Apulia, occurring also in the nearby Basilicata (Bartolucci et al., 2018).

Epipactis garganica is a recently described species (Hertel \& Presser, 2019), reported from a small part of the Umbra Forest, on the Gargano promontory. Ophrys gravinensis has also been described recently (D'Alonzo, 2015a). It is known to date only from the province of Bari, i.e. in Gravina in Puglia, Poggiorsini, Spinazzola, and Cassano delle Murge (D’Alonzo, 2015b). Ophrys mattinatae was described from Mattinata, on the Gargano promontory (Medagli et al., 2012). It was previously confused with Ophrys bremifera Steven, which is not present in Italy (Delforge, 2016). Until now it was known only from the type locality. Ophrys murgiana was described from Altamura, on the Murgia plateau (Medagli \& Cillo, 2009) and then found on other sites of the same area. Ophrys oestrifera subsp. montis-gargani is endemic to the northern part of the Gargano promontory. It was described from Peschici (Van de Vijver et al., 2010), and reported also from Vieste, Ischitella and Vico del Gargano (Lorenz \& Gembardt, 1987). It was previously confused with Ophrys scolopax Cav. subsp. cornuta (Steven) E.G.Camus and with Ophrys oestrifera subsp. oestrifera. As the southwesternmost representative of the east-Mediterranean $O$. oestrifera-complex (Van de Vijver et al., 2010), together with $O$. mattinatae, this taxon is one of the many examples of connections between the flora of Apulia and the flora of south-east Europe and the eastern Mediterranean region, as abundantly demonstrated by floristic (Peruzzi \& Caparelli, 2007; Karl \& Scholz, 2009; Wagensommer et al., 2014a,d, 2017) and vegetational (Bianco et al., 1988; Di Pietro \& Wagensommer, 2008, 2014) studies. Possibly it is explained by research on the palaeogeography of the Mediterranean area, that confirmed the existence of land connections between Apulia and the Balkans in the Oligocene and in the Miocene epochs, in particular during the Late Miocene (Tortonian and Messinian stages) (Azzaroli \& Guazzone, 1980; Musacchio et al., 2006; Mazza, 2013). Ophrys oxyrrhynchos subsp. ingrassiae was described from Martina Franca, in the province of Taranto (Dura et al., 2011), being then recorded from Cassano delle Murge, in the province of Bari (De Leo, 2016), and from Francavilla Fontana, in the province of Brindisi (Mascia, 2018). Ophrys pencetiae was described from Ruvo di Puglia, in the province of Bari (Turco et al., 2012). Until now it was known only from the type locality. Ophrys pseudomelena was described from San Cataldo (Vernole), in the Salento peninsula (Turco et al., 2012). It was previously confused with Ophrys lutea Cav. subsp. melena Renz. It is widespread in Apulia, occurring in the provinces of Foggia (Mattinata, Monte S. Angelo, Peschici, Vieste) (Lorenz \& Gembardt, 1987), Taranto (Mottola) (Turco et al., 2012) and Lecce (Vernole, Melendugno, Gallipoli) (Turco et al., 2012). Ophrys tardans was described from Lecce, in the Salento peninsula (Danesch \& Danesch, 1972). It is still known only from the province of Lecce, in Otranto (Gennaio \& Medagli, 2015), Collepasso (Gennaio et al., 2016) and Vernole (Lumare \& Medagli, 2017). The record from the province of Bari (Gravina in Puglia) (D’Alonzo, 2013) is erroneous (D’Alonzo, pers. com.). Finally, Serapias orientalis subsp. apulica was described from Siponto, near Manfredonia (Foggia) (Baumann \& Künkele, 1989). This taxon is currently known from many sites throughout Apulia (Lorenz \& Gembardt, 1987; Perrino \& Signorile, 2009; Turco \& Medagli, 2012; Perrino et al., 2013; Lumare \& Medagli, 2016; Lumare et al., 2016, 2018; Gennaio, 2017).

In the last years, a big effort has been carried out in many countries worldwide for the publication of red lists according to the IUCN protocol (e.g. Rassi et al., 2010; Bilz et al., 2011; González-Espinosa et al., 2011; Rakotoarinivo et al., 2014; Stroh et al. 2014; Qin et al., 2017). In Italy, the extinction risk of a great number of plant species has been evaluated in the last years, aiming at a new Italian Red List of vascular plants (Rossi et al., 2013, 2014, 2016; Orsenigo et al., 2018, 2020). Due to an increased effort in field research, many new data about the populations of different species of Orchidaceae in Apulia were collected in the last years. Following the IUCN protocol (IUCN, 2012a,b, 2019), more accurate information about distribution, occurring sites, number of individuals, trend of the populations, ecology of the species, threats affecting the populations, etc., can influence the extinction risk assessment results, especially in case of rare species (Wagensommer, 2010). Therefore, the aim of the present paper is the IUCN assessment of the ten orchid taxa currently considered endemic to Apulia, the comparison between the new assessments proposed in this study and the previous ones, and the evaluation of the results of this comparison: Are there category changes? If yes, why?

\section{Material and Methods}

Apulia is an administrative region in south-eastern Italy, covering an area of $19.541 \mathrm{~km}^{2}$. Floristic 
surveys were carried out in the whole Apulian region for all taxa, except for the recently described Epipactis garganica, from 2015 to 2019. During the surveys, carried out twice a week from 1 March to 31 May, new occurring sites were searched in suitable environments, and counts of individuals and the evaluation of threats in already known populations were carried out. For each taxon we collected also the data available from literature (Lorenz \& Gembardt, 1987; Medagli \& Cillo, 2009; Perrino \& Signorile, 2009; Van de Vijver et al., 2010; Dura et al., 2011; Medagli et al., 2012; Turco \& Medagli, 2012; Turco et al., 2012; Perrino et al., 2013; D’Alonzo, 2015a,b; Gennaio \& Medagli, 2015; De Leo, 2016; Gennaio et al. 2016; Lumare \& Medagli, 2016, 2017; Lumare et al., 2016, 2018; Gennaio, 2017; Mascia, 2018; Hertel \& Presser, 2019). All the data were then stored in a database, including occurring sites with geographic coordinates, trend of each population, number of mature individuals on each site (when available), threats identified by expert-based observations and then categorised according to the IUCN threats classification scheme (IUCN, 2012b), year of the more recent observation for each site.

The distribution data were stored in a geo-database, in which each georeferenced record was reported in a grid of $2 \times 2 \mathrm{~km}$ cells. The Extent of Occurrence (EOO) and Area of Occupancy (AOO) were calculated with Google Earth Pro. The EOO was measured by the minimum convex polygon (the smallest polygon in which no internal angle exceeds 180 degrees and which contains all the sites of occurrence), while the AOO was calculated using the grid of $2 \times 2 \mathrm{~km}$ cells. If the measured EOO was smaller than the AOO, its value was elevated to the same value of AOO. The occurrence in a Protected Area, especially in a national park, was highlighted in the geo-database. The national parks instituted in Apulia are: the Gargano National Park in the north of the region (province of Foggia) and the Alta Murgia National Park in the central part of the region (province of Bari and province of BarlettaAndria-Trani). The assessments (at global level) follow the IUCN protocol (IUCN, 2012a,b, 2019). The nomenclature and the taxonomic arrangement follow Bartolucci et al. (2018).

\section{Results and Discussion IUCN Global Assessments}

Epipactis garganica S.Hertel

Occurring sites: 13 .

Threats: No threats affecting the species. EOO: $8 \mathrm{~km}^{2}$.
AOO: $8 \mathrm{~km}^{2}$.

Locations sensu IUCN: No threats have been found.

Severely fragmented: No.

Extreme fluctuations: No.

Estimated number of mature individuals: ca. 100.

Continuing decline: No decline observed. No projected continuing decline.

Previous assessment: Not Evaluated (NE); Because of its recent description, this species had never been assessed before against the IUCN categories and criteria.

New assessment (criteria B, C, D): Endangered (EN D).

Notes: All occurring sites are inside the Gargano National Park.

\section{Ophrys gravinensis D’Alonzo}

Occurring sites: 6 .

Threats: 7.1 (Fire and fire suppression); 7.3 (Other ecosystem modifications).

EOO: $140 \mathrm{~km}^{2}$.

AOO: $20 \mathrm{~km}^{2}$.

Locations sensu IUCN: 3.

Severely fragmented: No.

Extreme fluctuations: No.

Estimated number of mature individuals: ca. 500.

Continuing decline: No decline observed. No projected continuing decline.

Previous assessment: EN D (Orsenigo et al., 2018).

New assessment (criteria B, C, D): Vulnerable (VU D1+2).

Notes: All occurring sites are inside the Alta Murgia National Park.

Ophrys mattinatae Medagli, A.Rossini, Quitadamo, D'Emerico \& Turco

Occurring sites: 3 .

Threats: 1.3 (Tourism and recreation areas); 4.1 (Roads and railroads).

EOO: $74 \mathrm{~km}^{2}$.

AOO: $12 \mathrm{~km}^{2}$.

Locations sensu IUCN: 3 .

Severely fragmented: No.

Extreme fluctuations: No.

Estimated number of mature individuals: ca. 200.

Continuing decline: No decline observed. No projected continuing decline.

Previous assessment: EN D (Orsenigo et al., 2018).

New assessment (criteria B, C, D): Endangered (EN D).

Notes: All occurring sites are inside the Gargano National Park. 
Ophrys murgiana Cillo, Medagli \& Margh.

Occurring sites: 8.

Threats: 1.1 (Housing and urban areas); 2.1 (Annual and perennial non-timber crops); 6.1 (Recreational activities).

EOO: $634 \mathrm{~km}^{2}$.

AOO: $32 \mathrm{~km}^{2}$.

Locations sensu IUCN: 6.

Severely fragmented: No.

Extreme fluctuations: No.

Estimated number of mature individuals: ca. 1800.

Continuing decline: Decline observed in one site near Altamura. Continuing decline projected, due to the detected threats.

Previous assessment: VU D2 (Orsenigo et al., 2018).

New assessment (criteria B, C, D): Endangered (EN C2a(ii)).

Notes: Four out of eight sites are inside the Alta Murgia National Park.

Ophrys oestrifera M.Bieb. subsp. montis-gargani Van de Vijver \& W.Looken

Occurring sites: 39 .

Threats: 1.3 (Tourism and recreation areas); 7.1 (Fire and fire suppression); 7.3 (Other ecosystem modifications).

EOO: $132 \mathrm{~km}^{2}$.

AOO: $72 \mathrm{~km}^{2}$.

Locations sensu IUCN: 6.

Severely fragmented: No.

Extreme fluctuations: No.

Estimated number of mature individuals: ca. 2500.

Continuing decline: No decline observed. Continuing decline projected, due to the detected threats.

Previous assessment: EN D (Orsenigo et al., 2018).

New assessment (criteria B, C, D): Vulnerable (VU B1ab(i,ii,iii,iv,v)+2ab(i,ii,iii,iv,v)).

Notes: The major part of the sites are inside the Gargano National Park. Only a few sites are outside the national park.

Ophrys oxyrrhynchos Tod. subsp. ingrassiae Dura, Turco, Gennaio \& Medagli

Occurring sites: 7.

Threats: 7.3 (Other ecosystem modifications).

EOO: $365 \mathrm{~km}^{2}$.

AOO: $28 \mathrm{~km}^{2}$.

Locations sensu IUCN: 4.

Severely fragmented: No.

Extreme fluctuations: No.

Estimated number of mature individuals: ca. 300.

Continuing decline: No decline observed. No projected continuing decline.
Previous assessment: NT (Orsenigo et al., 2018).

New assessment (criteria B, C, D): Vulnerable (VU D1).

Notes: One site (Cassano delle Murge) out of seven is included in the Alta Murgia National Park.

Ophrys pencetiae Lozito, D'Emerico, Medagli \& Turco

Occurring sites: 2.

Threats: No threats have been found affecting the species.

EOO: $8 \mathrm{~km}^{2}$.

AOO: $8 \mathrm{~km}^{2}$.

Locations sensu IUCN: No threats have been found.

Severely fragmented: No.

Extreme fluctuations: No.

Estimated number of mature individuals: ca. 350.

Continuing decline: No decline observed. No projected continuing decline.

Previous assessment: LC (Orsenigo et al., 2018).

New assessment (criteria B, C, D): Vulnerable (VU D1).

Notes: The two occurring sites are outside the boundaries of the national parks.

Ophrys pseudomelena Turco, Medagli \& D'Emerico

Occurring sites: 40.

Threats: 2.1 (Annual and perennial non-timber crops); 7.3 (Other ecosystem modifications).

EOO: $11510 \mathrm{~km}^{2}$.

AOO: $100 \mathrm{~km}^{2}$.

Locations sensu IUCN: 10.

Severely fragmented: No.

Extreme fluctuations: No.

Estimated number of mature individuals: ca. 2500.

Continuing decline: No decline observed, except on the sites of Mottola, Vernole and Gallipoli. No projected continuing decline.

Previous assessment: NT (Orsenigo et al., 2018).

New assessment (criteria B, C, D): Near Threatened (NT).

Notes: The major part of the sites occurring in the Gargano promontory are included in the Gargano National Park.

Ophrys tardans O.Danesch \& E.Danesch

Occurring sites: 6 .

Threats: 1.1 (Housing and urban areas); 1.3 (Tourism and recreation areas); 2.1 (Annual and perennial non-timber crops); 6.1 (Recreational activities).

EOO: $617 \mathrm{~km}^{2}$.

AOO: $24 \mathrm{~km}^{2}$.

Locations sensu IUCN: 4. 
Severely fragmented: No.

Extreme fluctuations: No.

Estimated number of mature individuals: ca. 800 .

Continuing decline: decline observed in two sites. Continuing decline projected.

Previous assessment: LC (Orsenigo et al., 2018).

New assessment (criteria B, C, D): Endangered (EN B1ab(i,ii,iii,iv,v)+2ab(i,ii,iii,iv,v)+C2a(ii)).

Notes: The occurring sites are not included in the national parks.

Serapias orientalis (Greuter) H.Baumann \& Künkele subsp. apulica H.Baumann \& Künkele

Occurring sites: 48.

Threats (especially on the sites near Manfredonia): 1.1 (Housing and Urban areas); 1.2 (Commercial and Industrial areas); 1.3 (Tourism and recreation areas).

EOO: $15354 \mathrm{~km}^{2}$.

AOO: $136 \mathrm{~km}^{2}$.

Locations sensu IUCN: 13.

Severely fragmented: No.

Extreme fluctuations: No.

Estimated number of mature individuals: ca. 3500.

Continuing decline: No decline observed, except in the area of Manfredonia (Foggia) and along the coast near Monopoli (Bari). No projected continuing decline.

Previous assessments: R (Conti et al., 1992); VU (Conti et al., 1997; see also Wagensommer et al., 2013); LC (Orsenigo et al., 2018).

New assessment (criteria B, C, D): Least Concern (LC).

Notes: Most of the sites are outside the boundaries of the national parks. Some sites are included in the Gargano National Park, and one site is included in the Alta Murgia National Park.

\section{Considerations to the assessments}

Endemic taxa are the most valuable component of a flora and deserve high regional and global conservation priorities (Schmeller et al., 2008; Brundu et al., 2017). The assessments of the species conservation status are considered effective tools to aid conservation planning and to evaluate conservation options (Orsenigo et al., 2018). Even if the IUCN protocol for assessing the conservation status of species has no legal implications, the scientific community has endorsed its use, even despite the errors that have been identified (Possingham et al., 2002; Mace et al., 2008). We agree with Anton et al. (2013) that this approach may represent a starting point for the legal categorisation of species. Nevertheless, as pointed out by Rossi et al. (2016), legal protec- tion alone is not sufficient to guarantee a good conservation status of the protected species.

The distribution maps (Fig. 1, Fig. 2) show areas where the species cluster together, where the highest diversity of species can be found. As highlighted by Orsenigo et al. (2018), the implications of these analyses are important because they allow the identification of areas of potential conservation importance and the focusing of direct conservation management actions in geographical areas with the highest levels of plant diversity (Crain et al., 2011) or with a high concentration of narrow endemic species (Wulff et al., 2013). In Apulia the territories with the highest number of sites and with the highest biodiversity of endemic orchids are the Gargano promontory in the north, the Murgia plateau in the central part of the region and the Salento peninsula in the south (Fig. 1, Fig. 2). This is certainly a consequence of the environmental characteristics of these territories, which show the highest environmental variability in the region (Blasi \& Biondi, 2017). The only territory in which a greater presence of sites has been expected is the area of the "Gravine» gorges in the province of Taranto, also characterised by a great environmental variability (Biondi \& Guerra, 2008; Di Pietro \& Misano, 2009, 2010). Perhaps, to fill this gap, a greater effort in field research would be necessary in the province of Taranto. On the other hand, the absence of sites of orchids endemic to Apulia in the Daunia Mts., another territory with a high environmental variability, is due to the proximity of this area to the Apennine mountain chain and to other Italian regions (Wagensommer et al., 2014b).

No taxon is classified as Critically Endangered. Nevertheless, eight of the ten assessed taxa are classified as threatened (four as Endangered and four as Vulnerable) and only two taxa are classified as non-threatened (one as Near Threatened and one as Least Concern) (Table). Despite many sites being included in the Gargano National Park and in the Alta Murgia National Park, many threats were detected, affecting also these populations included in the national parks. This demonstrates that the protection given by the national parks, albeit valuable for the conservation of wild biodiversity, cannot be considered sufficient. Targeted conservation actions are necessary for the conservation of the most threatened taxa. A monitoring programme is also warmly recommended, in order to better understand the population dynamics and how the detected threats negatively affect the populations. 


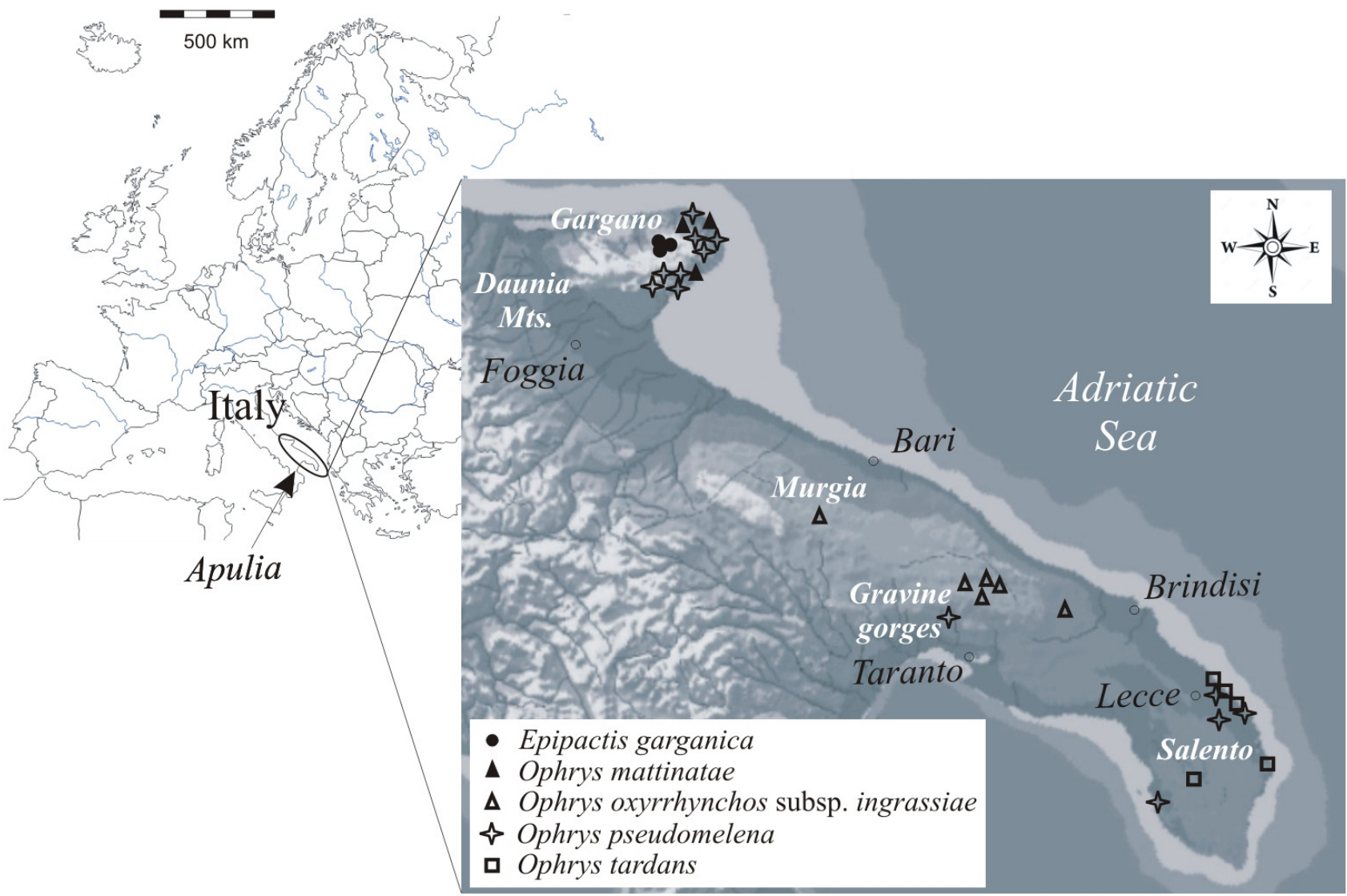

Fig. 1. Global distribution of Epipactis garganica, Ophrys mattinatae, O. oxyrrhynchos subsp. ingrassiae, O. pseudomelena, and $O$. tardans.

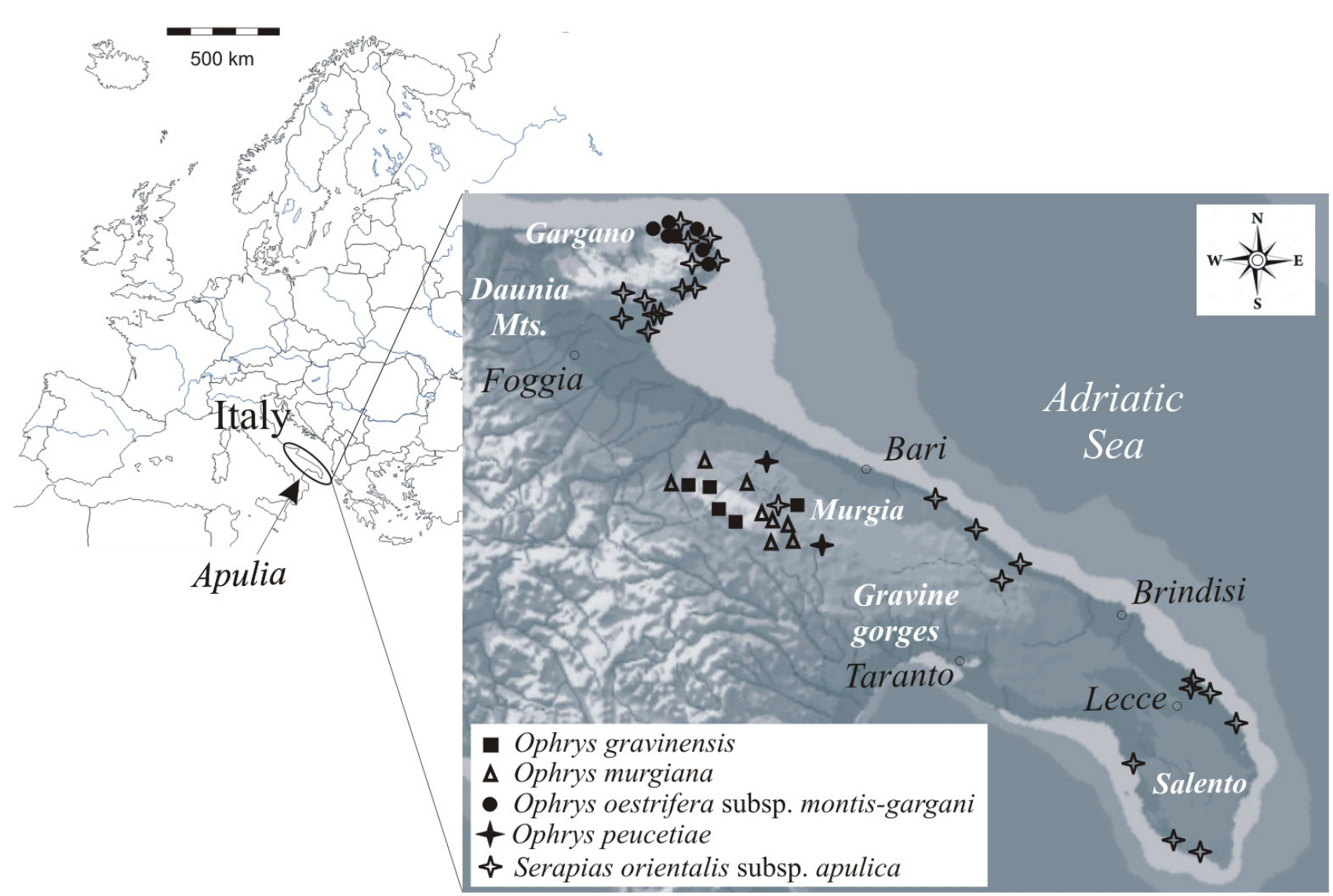

Fig. 2. Global distribution of Ophrys gravinensis, O. murgiana, O. oestrifera subsp. montis-gargani, O. peucetiae, and Serapias orientalis subsp. apulica. 
Table. Comparison between previous and new assessments

\begin{tabular}{|l|c|c|l|l|}
\hline \multicolumn{1}{|c|}{ Taxon } & $\begin{array}{c}\text { Previous assessment } \\
\text { (Orsenigo et al., 2018) }\end{array}$ & $\begin{array}{c}\text { Threats according to } \\
\text { Orsenigo et al. (2018) }\end{array}$ & New assessment & $\begin{array}{c}\text { Threats found in the } \\
\text { present assessment }\end{array}$ \\
\hline Epipactis garganica & Not evaluated & Not evaluated & EN D & No threats found \\
\hline Ophrys gravinensis & EN D & $5.2,7.1,7.3$ & VU D1+2 & $7.1,7.3$ \\
\hline Ophrys mattinatae & EN D & 4.1 & EN D & $1.3,4.1$ \\
\hline Ophrys murgiana & VU D2 & 2.1 & EN C2a(ii) & $1.1,2.1,6.1$ \\
\hline $\begin{array}{l}\text { Ophrys oestrifera } \\
\text { subsp. montis-gargani }\end{array}$ & EN D & $7.1,7.3$ & VU B1 ab(i,ii,iii,iv,v)+2ab(i,ii,iii,iv,v) & $1.3,7.1,7.3$ \\
\hline $\begin{array}{l}\text { Ophrys oxyrrhynchos } \\
\text { subsp. ingrassiae }\end{array}$ & NT & 7.3 & VU D1 & 7.3 \\
\hline Ophrys peucetiae & LC & No threats found & VU D1 & No threats found \\
\hline Ophrys pseudomelena & NT & 7.3 & NT & $2.1,7.3$ \\
\hline $\begin{array}{l}\text { Ophrys tardans } \\
\text { Serapias } \text { orientalis } \\
\text { subsp. apulica }\end{array}$ & LC & No threats found & EN B1ab(i,ii,iii,iv,v)+2ab(i,ii,iii,iv,v)+C2a(ii) & $1.1,1.3,2.1,6.1$ \\
\hline
\end{tabular}

According to the IUCN threats classification scheme (IUCN, 2012b), the most common threats affecting the analysed species are enlargement of human settlements and tourist facilities, and other ecosystem modifications, followed by agricultural activities. That is in accordance with other recent assessments, also on living groups different from plants, such as fungi (Wagensommer et al., 2018) and animals (Temple \& Terry, 2009). Human pressure connected with agriculture, residential and commercial development or recreational activities was already recognised as a key driver of extinction risk (Underwood et al., 2009; Orsenigo et al., 2018). Especially in coastal areas, tourism and recreational activities have negative impacts on plants, as already pointed out by other authors (Ballantyne \& Pickering, 2013).

Nine of the ten analysed taxa were recently assessed against the IUCN categories and criteria (Orsenigo et al., 2018). However, in the last few years many new data were collected in Apulia on the distribution, threats and population size of the taxa belonging to the family Orchidaceae, due to an increased field activity. That can explain why six of these nine taxa (67\%) changed their IUCN category (Table, Fig. 3).

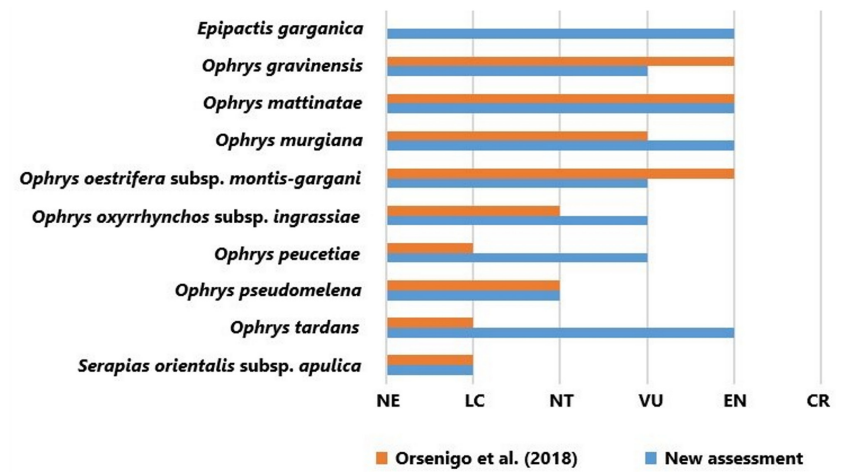

Fig. 3. IUCN category change from the previous to the present assessments.
Four taxa (Ophrys murgiana, O. oxyrrhynchos subsp. ingrassiae, O. peucetiae, O. tardans) are now assigned to a higher threat category, while two taxa (Ophrys gravinensis and O. oestrifera subsp. montisgargani) are now assigned to a lower threat category (Fig. 3). These category changes in such a very short time are due to the better knowledge on the number of mature individuals and on the threats affecting the species, and to the discovery of new sites. The most important category change affects Ophrys tardans. The new assessment leads to the category Endangered, whereas in the previous assessment this species was indicated as Least Concern, i.e. as not threatened. This completely different assessment is primarily due to the better knowledge of the threats affecting this species (Orsenigo et al. (2018) indicated no threats for this species) together with the observed and projected decline, and secondarily to the count of the number of mature individuals, which was not known until now. Another species with a noteworthy category increase is Ophrys peucetiae, previously indicated as Least Concern and now assigned to the category Vulnerable. This change is due to the count of the number of mature individuals. In fact, the population size was unknown to date, and therefore Orsenigo et al. (2018) could not assess this species against subcriterion D1. The other taxa are characterised by a single category increase or decrease. In the previous assessment (Orsenigo et al., 2018), all the taxa falling in a threat category (CR, EN, VU) were assigned to their category according to criterion D. In the present assessment, five taxa were assigned to their threat category according to criterion $\mathrm{D}$, and three taxa according to other criteria (one taxon according to criterion $\mathrm{B}$, one taxon according to criterion $\mathrm{C}$ and one taxon according to both criteria $\mathrm{B}$ and $\mathrm{C}$ ). This is the result of a better knowledge of the threats affecting the species and of the population dynamics (increasing, stable or declining populations), both necessary for the assessment against the criteria $\mathrm{B}$ and $\mathrm{C}$. 
Given that rare species are intrinsically characterised by an exiguous number of sites, fortuitous discovery of new sites is quite uncommon. Though, targeted field research often leads to the detection of still unknown sites (Wagensommer, 2010). The following new sites were found during the floristic surveys: Ophrys mattinatae near Vieste and in Umbra Forest (near Caserma Caritate), O. murgiana in Ruvo di Puglia, Cassano delle Murge, Spinazzola and Andria, O. oxyrrhynchos subsp. ingrassiae in Crispiano, $O$. peucetiae in Santeramo in Colle, O. tardans in Melendugno, Serapias orientalis subsp. apulica in Altamura, Cisternino and Melendugno. Assessing rare species, the discovery of a single or few new occurring sites could lead to a different IUCN category. In fact, the new sites could noteworthy change the knowledge on the threats actually affecting the species (used for the assessment against the criteria B and C), or lead to a better estimation of the number of mature individuals (used for the assessment against the criteria $C$ and $D$ ). The same result could be obtained by a better knowledge of threats and population size in already known occurring sites. Therefore, an in-depth field research is warmly suggested before assessing the IUCN threat category of rare taxa with a small distribution range.

\section{Conclusions}

We consider our assessments a first step in the conservation of the Orchidaceae endemic to Apulia. Given that eight of the ten assessed taxa are classified as threatened, a monitoring programme is necessary in the next years to guarantee their current conservation status. Monitoring activities will allow to a better understanding of the threats affecting the species and population dynamics. This information will be of great help for the possible implementation in future of in situ and/or ex situ conservation actions. In addition, our assessments will allow in future to assess these species also against the criterion A of the IUCN protocol. In fact, it will be possible to define a trend of the populations and to highlight a possible reduction. The comparison between our new assessments and the previous ones shows that $2 / 3$ of the taxa changed their IUCN category. These changes demonstrate that to be consistent, the assessments against the IUCN criteria of rare species with a small distribution range need to be preceded by targeted field research, because of the importance of an in-depth knowledge on the effective occurring sites, population size and threats actually affecting the populations. Without this foregoing step, the results of the assessments could be not appropriate. Therefore, we recommend that who are engaged in the IUCN assessments of rare taxa always take into due consideration this aspect.

\section{Acknowledgements}

The authors are grateful to Mirella Campochiaro, Nicola Cillo, Filippo D’Alonzo, Vincenzo De Leo, Teo Dura, Filomeno Leone, Febo Lumare, Giovanni Quitadamo, Angela Rossini, and Anna Scardigno for providing unpublished data regarding the distribution and size of some recently found populations.

\section{References}

AA.VV. 2016. Orchidee d'Italia. Guida alle orchidee spontanee. Seconda Edizione. Cornaredo (MI): Ed. Il Castello. 368 p.

Anton M., Estrada J., Herrando S. 2013. The Red List of Catalan breeding birds (NE Iberian Peninsula). Revista Catalana d'Ornitologia 29(2012): 1-19.

Azzaroli A., Guazzone G. 1980. Terrestrial mammals and land connections in the mediterranean before and during the messinian. Palaeogeography, Palaeoclimatology, Palaeoecology 29: 155-167. DOI: 10.1016/0031-0182(79)90079-8

Ballantyne M., Pickering C.M. 2013. Tourism and recreation: A common threat to IUCN red-listed vascular plants in Europe. Biodiversity and Conservation 22(13-14): 3027-3044. DOI: 10.1007/s10531-013-0569-2

Bartolucci F., Peruzzi L., Galasso G., Albano A., Alessandrini A., Ardenghi N.M.G., Astuti G., Bacchetta G., Ballelli S., Banfi E., Barberis G., Bernardo L., Bouvet D., Bovio M., Cecchi L., Di Pietro R., Domina G., Fascetti S., Fenu G., Festi F., Foggi B., Gallo L., Gottschlich G., Gubellini L., Iamonico D., Iberite M., Jiménez-Mejías P., Lattanzi E., Marchetti D., Martinetto E. et al. 2018. An updated checklist of the vascular flora native to Italy. Plant Biosystems 152(2): 179-303. DOI: 10.1080/11263504.2017.1419996

Baumann H., Künkele S. 1989. Die Gattung Serapias L. - Eine taxonomische Übersicht. Mitteilungsblatt des Arbeitskreises Heimische Orchideen Baden-Württemberg 21(3): 701-946.

Bianco P., Brullo S., Pignatti E., Pignatti S. 1988. La vegetazione delle rupi calcaree della Puglia. Braun Blanquetia 2: 133-151.

Bilz M., Kell S.P., Maxted N., Lansdown R.V. 2011. European Red List of vascular plants. Luxembourg: Publications Office of the European Union. $130 \mathrm{p}$.

Biondi E., Guerra V. 2008. Vegetazione e paesaggio vegetale delle gravine dell'arco jonico. Fitosociologia 45(1)suppl.1: 57-125.

Blasi C., Biondi E. (Eds.). 2017. La flora in Italia. Roma: Ministero dell'Ambiente e della Tutela del Territorio e del Mare, Sapienza Università Editrice. 704 p.

Brundu G., Peruzzi L., Domina G., Bartolucci F., Galasso G., Peccenini S., Raimondo F.M., Albano A., Alessandrini A., Banfi E., Barberis G., Bernardo L., Bo- 
vio M., Brullo S., Brunu A., Camarda I., Carta L., Conti F., Croce A., Iamonico D., Iberite M., Iiriti G., Longo D., Marsili S., Medagli P., Mariotti M.G., Pennesi R., Pistarino A., Salmeri C., Santangelo A. et al. 2017. At the intersection of cultural and natural heritage: Distribution and conservation of the type localities of Italian endemic vascular plants. Biological Conservation 214: 109-118. DOI: 10.1016/j.biocon.2017.07.024

Conti F., Manzi A., Pedrotti F. 1992. Libro Rosso delle Piante d'Italia. Roma: Ministero Ambiente, WWF Italia, Società Botanica Italiana. 637 p.

Conti F., Manzi A., Pedrotti F. (Eds.). 1997. Liste Rosse Regionali delle Piante d'Italia. Camerino: WWF Italia, Società Botanica Italiana, CIAS. 139 p.

Crain B.J., White J.W., Steinberg S.J. 2011. Geographic discrepancies between global and local rarity richness patterns and the implications for conservation. Biodiversity and Conservation 20(14): 3489-3500. DOI: $10.1007 / \mathrm{s} 10531-011-0137-6$

D’Alonzo F. 2013. Le Orchidee della Murgia barese e materana. Parco Nazionale dell'Alta Murgia barese - Parco Regionale della Murgia materana - Bosco Difesa Grande. GIROS Notizie 54: 24-37.

D’Alonzo F. 2015a. Ophrys gravinensis, nuova specie endemica della Puglia. Orchidee Spontanee d'Europa 58(1): 98-106.

D’Alonzo F. 2015b. Nuove stazioni di Ophrys gravinensis in Puglia e descrizione di due suoi ibridi. Orchidee Spontanee d'Europa 58(2): 247-261.

Danesch O., Danesch E. 1972. Orchideen Europas, Ophrys-Hybriden. Berg and Stuttgart: Hallawag Verlag. $270 \mathrm{p}$.

De Leo V. 2016. Due importanti ritrovamenti di Ophrys nella Murgia barese: O. crabronifera subsp. pollinensis (prima segnalazione in Puglia) e O. oxyrrhynchos subsp. ingrassiae (prima segnalazione nella provincia di Bari). Orchidee Spontanee d'Europa 59(2): 329-333.

Delforge P. 2016. Guide des Orchidées d'Europe, d'Afrique du Nord et du Proche-Orient. $4^{\text {th }} \mathrm{ed}$. Lausanne: Delachaux et Niestlé. 544 p.

Di Pietro R., Misano G. 2009. Analisi fitosociologica e considerazioni sintassonomiche sulla vegetazione forestale delle Gravine occidentali dell'Arco Ionico (Murge pugliesi e lucane, Italia meridionale). Informatore Botanico Italiano 41(2): 215-246.

Di Pietro R., Misano G. 2010. Shrubland and garrigue vegetation in the «Gravine» gorges (Apulia region, south-eastern Italy). Acta Botanica Gallica 157(2): 195-229. DOI: 10.1080/12538078.2010.10516199

Di Pietro R., Wagensommer R.P. 2008. Analisi fitosociologica su alcune specie rare e/o minacciate del Parco Nazionale del Gargano (Italia centro-meridionale) e considerazioni sintassonomiche sulle comunità casmofitiche della Puglia. Fitosociologia 45(1): 177-200.
Di Pietro R., Wagensommer R.P. 2014. A new Sesleria juncifolia association from south-eastern Italy and its position in the amphi-Adriatic biogeographical context. Acta Botanica Croatica 73(1): 171-207. DOI: 10.2478/botcro-2013-0018

Dura T., Turco A., Gennaio R., Medagli P. 2011. Una nuova entità della Puglia: Ophrys oxyrrhynchos Tod. subsp. ingrassiae Dura, Turco, Gennaio \& Medagli. GIROS Notizie 46: 37-39.

Gennaio R. 2017. Serapias apulica subsp. uxentina, un nuovo taxon salentino (Puglia). Orchidee Spontanee d'Europa 60(2): 347-360.

Gennaio R., Medagli P. 2015. Ophrys $\times$ sulphurea Gennaio \& Medagli, nuovo ibrido naturale del Salento (Puglia). Orchidee Spontanee d'Europa 58(1): 110-113.

Gennaio R., Gargiulo M., Medagli P., Chetta F.S. 2016. Ophrys $\times$ angelarum $(O$. bertolonii $\times O$. tardans $)$ nuovo ibrido naturale del Salento (Puglia). Orchidee Spontanee d'Europa 59(2): 334-338.

Gölz P., Reinhard H. 1982. Orchideen in Süditalien. Mitteilungsblatt des Arbeitskreises Heimische Orchideen Baden-Württemberg 14(1): 1-124.

González-Espinosa M., Meave J.A., Lorea-Hernández F.G., Ibarra-Manríquez G., Newton A.C. 2011. The Red List of Mexican cloud forest trees. Cambridge: Fauna \& Flora International. 149 p.

Hertel S., Presser H. 2019. Weitere Erkenntnisse zur Vielfalt der Epipactis-Arten im südlichen Italien. Berichte aus den Arbeitskreisen Heimische Orchideen 36(1): 5-61.

IUCN. 2012a. IUCN Red List Categories and Criteria: Version 3.1, second ed. Gland, Switzerland and Cambridge, UK: IUCN. 32 p.

IUCN. 2012b. Unified classification of direct threats: Version 3.2. IUCN CMP. Available from https:// s3.amazonaws.com/iucnredlist-newcms/staging/public/attachments/3127/dec_2012_guidance_threats_ classification_scheme.pdf

IUCN. 2019. Guidelines for using the IUCN Red List categories and criteria: Version 14. IUCN Standards and Petitions Subcommittee. Available from http://www. iucnredlist.org/documents/RedListGuidelines.pdf.

Karl R., Scholz H. 2009. Bromus parvispiculatus H. Scholz. In: W. Greuter, Th. Raus (Eds.): MedChecklist Notulae 28. Willdenowia 39(2): 340. DOI: 10.3372/wi.39.39211

Lorenz R., Gembardt C. 1987. Die Orchideenflora des Gargano (Italien). Mitteilungsblatt des Arbeitskreises Heimische Orchideen Baden-Württemberg 19(3): 385-756.

Lumare F., Medagli P. 2016. Segnalazione dell'ibrido Serapias $\times$ garganica notosubsp. garganica $(S$. orientalis subsp. apulica $\times S$. vomeracea subsp. longipetala) presso Lecce (Salento, Puglia). Orchidee Spontanee d'Europa 59(1): 196-204.

Lumare F., Medagli P. 2017. Ritrovamento di un nuovo ibrido naturale nel Salento: Ophrys $\times$ silvanae $(O$. 
candica $\times$ O.tardans). Orchidee Spontanee d'Europa 60(2): 481-494.

Lumare F., Medagli P., Zupo V. 2016. Studio morfometrico su una popolazione di Serapias orientalis subsp. apulica presso Lecce (Salento, Puglia). Orchidee Spontanee d'Europa 59(1): 107-119.

Lumare F., Medagli P., Rossini A., Quitadamo G. 2018. Studio di approfondimento su alcune sottospecie pugliesi di Serapias apulica. Orchidee Spontanee d'Europa 61(2): 444-459.

Mace G.M., Collar N.J., Gaston K.J., Hilton-Taylor C., Akçakaya H.R., Leader-Williams N., Milner-Gulland E.J., Stuart S.N. 2008. Quantification of extinction risk: IUCN's system for classifying threatened species. Conservation Biology 22(6): 1424-1442. DOI: 10.1111/j.1523-1739.2008.01044.x

Manni Q.G. 2016. Ophrys nicolae. A new species of the Sectio Arachnitiformes found in Salento (Apulia, South Italy). Journal Europäischer Orchideen 48(2-4): 283-302.

Mascia G. 2018. Ophrys oxyrrhynchos subsp. ingrassiae, prima segnalazione per la provincia di Brindisi. Orchidee Spontanee d'Europa 61(1): 87-90.

Mascia G., Labadessa R. 2019. La presenza in Puglia di Ophrys fusca subsp. calocaerina. Orchidee Spontanee d'Europa 62(1): 36-40.

Mazza P.P.A. 2013. The systematic position of Hoplitomerycidae (Ruminantia) revisited. Geobios 46(1-2): 33-42. DOI: 10.1016/j.geobios.2012.10.009

Medagli P., Cillo N. 2009. Ophrys murgiana Cillo, Medagli \& Margherita, specie nuova delle Murge (Puglia, Italia meridionale). GIROS Notizie 41: 23-25.

Medagli P., Rossini A., Quitadamo G., D’Emerico S., Turco A. 2012. Ophrys mattinatae, specie nuova del Gargano. GIROS Notizie 51: 102-103.

Musacchio A., Pellegrino G., Cafasso D., Widmer A., Cozzolino S. 2006. A unique $A$. palustris lineage across the Otranto strait: botanical evidence for a past landbridge? Plant Systematics and Evolution 262(1-2): 103-111. DOI: 10.1007/s00606-006-0469-y

Orsenigo S., Montagnani C., Fenu G., Gargano D., Peruzzi L., Abeli T., Alessandrini A., Bacchetta G., Bartolucci F., Bovio M., Brullo C., Brullo S., Carta A., Castello M., Cogoni D., Conti F., Domina G., Foggi B., Gennai M., Gigante D., Iberite M., Lasen C., Magrini S., Perrino E.V., Prosser F., Santangelo A., Selvaggi A., Stinca A., Vagge I., Villani M. et al. 2018. Red Listing plants under full national responsibility: Extinction risk and threats in the vascular flora endemic to Italy. Biological Conservation 224: 213-222. DOI: 10.1016/j.biocon.2018.05.030

Orsenigo S., Fenu G., Gargano D., Montagnani C., Abeli T., Alessandrini A., Bacchetta G., Bartolucci F., Carta A., Castello M., Cogoni D., Conti F., Domina G., Foggi B., Gennai M., Gigante D., Iberite M., Peruzzi L., Pinna M.S., Prosser F., Santangelo
A., Selvaggi A., Stinca A., Villani M., Wagensommer R.P., Tartaglini N., Duprè E., Blasi C., Rossi G. 2020. Red List of threatened vascular plants in Italy. Plant Biosystems. Published on-line. DOI: 10.1080/11263504.2020.1739165

Perrino E.V., Signorile G. 2009. Costa di Monopoli (Puglia): checklist della flora vascolare. Informatore Botanico Italiano 41(2): 263-279.

Perrino E.V., Signorile G., Marvulli M. 2013. A first checklist of the vascular flora of the Polignano a Mare coast (Apulia, southern Italy). Natura Croatica 22(2): 295-318.

Peruzzi L., Caparelli K.F. 2007. Gagea peduncularis (J. \& C. Presl) Pascher (Liliaceae) new for the Italian flora. Webbia 62(2): 261-268. DOI: 10.1080/00837792.2007.10670827

Peruzzi L., Conti F., Bartolucci F. 2014. An inventory of vascular plants endemic to Italy. Phytotaxa 168(1): 1-75. DOI: 10.11646/phytotaxa.168.1.1

Possingham H.P., Andelman S.J., Burgman M.A., Medellin R.A., Master L.L., Keith D.A. 2002. Limits to the use of threatened species lists. Trends in Ecology and Evolution 17(11): 503-507. DOI: 10.1016/S01695347(02)02614-9

Qin H., Yang Y., Dong S., He Q., Jia Y., Zhao L., Yu S., Liu H., Liu B., Yan Y., Xiang J., Xia N., Peng H., Li Z., Zhang Z., He X., Yin L., Lin Y., Liu Q., Hou Y., Liu Y., Liu Q., Cao W., Li J., Chen S., Jin X., Gao T., Chen W., Ma H., Geng Y. et al. 2017. Threatened species list of China's higher plants. Biodiversity Science 25(7): 696-744. DOI: 10.17520/biods.2017144

Rakotoarinivo M., Dransfield J., Bachman S.P., Moat J., Baker W.J. 2014. Comprehensive Red List assessment reveals exceptionally high extinction risk to Madagascar palms. PLoS ONE 9(7): e103684. DOI: 10.1371/journal.pone.0103684

Rassi P., Hyvärinen E., Juslén A., Mannerkoski I. (Eds.). 2010. The 2010 Red List of Finnish species. Helsinki: Ministry of the Environment, Finnish Environment Institute. $685 \mathrm{p}$.

Romolini R., Souche R. 2012. Ophrys d'Italia. Saint-Martin-de-Londres: Editions Sococor. 575 p.

Rossi G., Montagnani C., Gargano D., Peruzzi L., Abeli T., Ravera S., Cogoni A., Fenu G., Magrini S., Gennai M., Foggi B., Wagensommer R.P., Venturella G., Blasi C., Raimondo F.M., Orsenigo S. (Eds.). 2013. Lista Rossa della Flora Italiana. 1. Policy Species e altre specie minacciate. Roma: Comitato Italiano IUCN, Ministero dell'Ambiente e della Tutela del Territorio e del Mare, Stamperia Romana. 54 p.

Rossi G., Montagnani C., Abeli T., Gargano D., Peruzzi L., Fenu G., Magrini S., Gennai M., Foggi B., Wagensommer R.P., Ravera S., Cogoni A., Aleffi M., Alessandrini A., Bacchetta G., Bagella S., Bartolucci F., Bedini G., Bernardo L., Bovio M., Castello M., Conti F., Domina G., Farris E., Gentili R., 
Gigante D., Peccenini S., Persiani A.M., Poggio L., Prosser F. et al. 2014. Are Red Lists really useful for plant conservation? The New Red List of the Italian Flora in the perspective of national conservation policies. Plant Biosystems 148(2): 187-190. DOI: 10.1080/11263504.2013.868375

Rossi G., Orsenigo S., Montagnani C., Fenu G., Gargano D., Peruzzi L., Wagensommer R.P., Foggi B., Bacchetta G., Domina G., Conti F., Bartolucci F., Gennai M., Ravera S., Cogoni A., Magrini S., Gentili R., Castello M., Blasi C., Abeli T. 2016. Is legal protection sufficient to ensure plant conservation? The Italian Red List of policy species as a case study. Oryx 50(3): 431-436. DOI: 10.1017/S003060531500006X

Schmeller D.S., Gruber B., Budrys E., Framsted E., Lengyel S., Henle K. 2008. National responsibilities in European species conservation: A methodological review. Conservation Biology 22(3): 593-601. DOI: 10.1111/j.1523-1739.2008.00961.x

Stroh P.A., Leach S.J., August T.A., Walker K.J., Pearman D.A., Rumsey F.J., Harrower C.A., Fay M.F., Martin J.P., Pankhurst T., Preston C.D., Taylor I. 2014. A vascular plant Red List for England. Dorchester: Henry Ling Limited \& Bristol; Botanical Society of Britain and Ireland. 184 p.

Temple H.J., Terry A. 2009. European mammals: Red List status, trends, and conservation priorities. Folia Zoologica 58(3): 248-269.

Turco A., Medagli P. 2012. Serapias $\times$ gennaioi (Serapias cordigera $\times$ Serapias orientalis subsp. apulica), ibrido naturale nuovo del Salento. GIROS Notizie 49: 68-70.

Turco A., D’Emerico S., Lozito L., Medagli P. 2012. Ophrys peucetiae e Ophrys pseudomelena, due nuovi taxa per la Puglia. GIROS Notizie 50: 4-11.

Underwood E.C., Viers J.H., Klausmeyer K.R., Cox R.L., Shaw M.R. 2009. Threats and biodiversity in the Mediterranean biome. Diversity and Distributions 15(2): 188-197. DOI: 10.1111/j.1472-4642.2008.00518.x

Van de Vijver B., Van Looken W., Thiers G., Cuypers A. 2010. Ophrys oestrifera subsp. montis-gargani, a new subspecies from the Gargano (Italy). Journal Europäischer Orchideen 42(1): 167-180.

Wagensommer R.P. 2010. Indagini sulla distribuzione puntuale delle specie rare: alcuni casi studio della flora del Gargano (Puglia). Informatore Botanico Italiano 42(2): 451-463.

Wagensommer R.P., Medagli P., Perrino E.V. 2013. Piante vascolari minacciate e Liste Rosse: aggiornamento delle conoscenze in Puglia. Informatore Botanico Italiano 45(2): 422-428.

Wagensommer R.P., Fröhlich T., Fröhlich M. 2014a. First record of the southeast European species Cerinthe retorta Sibth. \& Sm. (Boraginaceae) in Italy and considerations on its distribution and conservation status. Acta Botanica Gallica 161(2): 111-115. DOI: 10.1080/12538078.2014.892438

Wagensommer R.P., Marrese M., Perrino E.V., Bartolucci F., Cancellieri L., Carruggio F., Conti F., Di Pietro R., Fortini P., Galasso G., Lattanzi E., Lavezzo P., Longo D., Peccenini S., Rosati L., Russo G., Salerno G., Scoppola A., Soldano A., Stinca A., Tilia A., Turco A., Medagli P., Forte L. 2014b. Contributo alla conoscenza floristica della Puglia: resoconto dell'escursione del Gruppo di Floristica (S.B.I.) nel 2011 nel settore meridionale dei Monti della Daunia. Informatore Botanico Italiano 46(2): 175-208.

Wagensommer R.P., Medagli P., Albano A., Peruzzi L., Bartolucci F., Villani M., Conti F., Passalacqua N.G., Alessandrini A., Barberis G., Bernardo L., Banfi E., Croce A., Domina G., Galasso G., Peccenini S., Pistarino A., Santangelo A. 2014c. Loci classici delle piante vascolari endemiche italiane descritte per la Puglia. Informatore Botanico Italiano 46(2): 359-362.

Wagensommer R.P., Perrino E.V., Silletti G.N. 2014d. Carex phyllostachys C.A. Mey. (Cyperaceae) new for Italy and phytogeographical considerations. Phyton (Horn, Austria) 54(2): 215-222. DOI: 10.12905/0380.phyton54(2)2014-0215

Wagensommer R.P., Bartolucci F., Fiorentino M., Licht W., Peccenini S., Perrino E.V., Venanzoni R. 2017. First record for the flora of Italy and lectotypification of the name Linum elegans (Linaceae). Phytotaxa 296(2): 161-170. DOI: 10.11646/ phytotaxa.296.2.5

Wagensommer R.P., Bistocchi G., Arcangeli A., Rubini A., Perini C., Venanzoni R., Angelini P. 2018. An assessment of red list data for the Pezizomycotina (Ascomycota): Umbria (Italy) as a test case. Plant Biosystems 152(6): 1329-1337. DOI: 10.1080/11263504.2018.1448015

Wulff A.S., Hollingsworth P.M., Ahrends A., Jaffré T., Veillon J.-M., L'Huillier L., Fogliani B. 2013. Conservation priorities in a biodiversity hotspot: Analysis of narrow endemic plant species in New Caledonia. PLoS ONE 8(9): e73371. DOI: 10.1371/journal. pone. 0073371 
ОЦЕНКА ОРХИДЕЙ-ЭНДЕМИКОВ АПУЛИИ (ИТАЛИЯ), СОГЛАСНО КРИТЕРИЯМ КРАСНОГО СПИСКА МСОП, И СООБРАЖЕНИЯ ПО ПРИМЕНЕНИЮ ПРОТОКОЛА МСОП К РЕДКИМ ВИДАМ

\author{
Р. Ф. Вагенсоммер ${ }^{1}$, П. Медали르, А. Турко 2 , Е. В. Перрино \\ ${ }^{1}$ Университет Бари «Альдо Моро», Италия \\ e-mail:robert.wagensommer@uniba.it \\ ${ }^{2}$ Университет Саленто, Италия \\ e-mail: pietro.medagli@unisalento.it,alessio.turco@unisalento.it \\ ${ }^{3}$ Средиземноморский агрономический институт г. Ханья, Италия \\ e-mail:perrino@iamb.it
}

В настоящей работе представлен охранный статус десяти видов и подвидов орхидных (восемь таксонов рода Ophrys и по одному таксону родов Epipactis и Serapias), эндемичных для региона Апулия (юго-восточная Италия). Каждый таксон был оценен согласно критериям и категориям Красного списка МСОП, принятым на международном уровне. Из десяти таксонов, восемь были отнесены к угрожаемым (Исчезающий (EN) или Уязвимый (VU)), один таксон - как находящийся в состоянии, близком к угрожаемому (NT), и один таксон - как вызывающий наименьшие опасения (LC). Учитывая, что девять из десяти анализируемых видов уже были ранее оценены, мы провели сравнение их прежнего статуса с результатами новой оценки. В результате было показано, что $67 \%$ оцененных таксонов сменили категорию Красного списка МСОП. Для четырех таксонов (Ophrys murgiana, O. oxyrrhynchos subsp. ingrassiae, O. peucetiae, O. tardans) отмечено повышение категории угрозы исчезновения, тогда как для двух таксонов (Ophrys gravinensis and O. oestrifera subsp. montis-gargani) категория угрозы исчезновения была понижена в результате проведенной оценки. Эти изменения категорий Красного списка в такое короткое время объясняются получение более полных данных о количестве половозрелых особей, об угрозах для популяций этих таксонов, и выявлении новых местонахождений орхидей. Самое значительное изменение категории касается Ophrys tardans, который был оценен как «Угрожаемый» (EN), тогда как предыдущая оценка этого вида указала его статус, как «Вызывающий наименьшие опасения» (LC), т.е. не являвшимся угрожаемым таксоном. Другой вид, категория которого заметно повысилась, это Ophrys peucetiae. Тогда как прежде он был оценен как «Вызывающий наименьшие опасения» (LC), в результате настоящего исследования этот вид получил оценку «Уязвимый» (VU). Авторами обсуждаются эти результаты, Авторы обсуждают эти результаты, подчеркивая необходимость учитывать, что на оценку могут влиять (что примечательно) эффективные знания о распространении, размере популяций и угрозы, влияющих на популяции. Это особенно важно при оценке, согласно протоколу МСОП, редких видов с небольшим ареалом. Как следствие, перед оценкой категории угрозы редких таксонов настоятельно рекомендуется проводить полевые исследования, учитывая, что увеличение интенсивности полевых исследований часто приводит к выявлению новых местонахождений видов и более точной оценке количества особей в популяциях и угроз им.

Ключевые слова: Апулия, изменение категории, орхидные, охрана, распространение, риск исчезновения, угрозы, эндемизм 